\title{
Comment on
}

\section{"Soil $\mathrm{CO}_{2}, \mathrm{CH}_{4}$ and $\mathrm{N}_{2} \mathrm{O}$ fluxes from an afforested lowland raised peat bog in Scotland: implications for drainage and restoration" by Yamulki et al. (2013)}

\author{
R. R. E. Artz ${ }^{1}$, S. J. Chapman ${ }^{1}$, M. Saunders ${ }^{1}$, C. D. Evans $^{2}$, and R. B. Matthews ${ }^{1}$ \\ ${ }^{1}$ The James Hutton Institute, Craigiebuckler, Aberdeen, AB15 8QH, UK \\ ${ }^{2}$ Centre for Ecology and Hydrology, Environment Centre Wales, Bangor, Deiniol Road, Bangor, Gwynedd, LL57 2UW, UK \\ Correspondence to: R. Artz (rebekka.artz@hutton.ac.uk)
}

Received: 17 May 2013 - Published in Biogeosciences Discuss.: 25 June 2013

Revised: 8 October 2013 - Accepted: 14 October 2013 - Published: 22 November 2013

\begin{abstract}
Yamulki and co-authors address in their recent publication the important issue of net emissions of greenhouse gases (GHGs) from peatlands where land use conversion has taken place. In their case, they studied conversion to forestry versus peatland restoration after a first rotation of plantation forestry. They monitored soil-derived fluxes of carbon dioxide $\left(\mathrm{CO}_{2}\right)$, methane $\left(\mathrm{CH}_{4}\right)$ and nitrous oxide $\left(\mathrm{N}_{2} \mathrm{O}\right)$ using opaque chamber measurements on planted and unplanted control treatments (with or without drainage), and an unplanted plot within a restored (felled) block on former lowland raised bog. They propose that their measurements of greenhouse gas (GHG) emissions at these sites suggest that the total net GHG emissions, in $100 \mathrm{yr}$ carbon dioxide equivalents, of the restored peat bog would be higher than that of the peat bog with trees. We believe there are a number of issues with the measurement, calculation and comparison of these greenhouse budgets that may invalidate this conclusion.
\end{abstract}

\section{Discussion}

The study of Yamulki et al. (2013) presents valuable measurements of greenhouse gas emissions from two sites located on a former lowland raised bog in Scotland, UK. The first site includes experimental treatments of afforested or unplanted areas, in combination with or without drainage. The second site is an unmanaged area, which is located within a block where a surrounding forestry rotation was felled and drains were blocked as part of a restoration treatment implemented in 1998. They calculate estimates of greenhouse gas (GHG) balances for the experimental treatments based on a combination of measurements and literature data. Such data are of high policy relevance to national governments in the light of national GHG emissions accounting. Although lowland raised bogs constitute only a small proportion of the total peatland area in the UK, national GHG emissions are accounted for at the level of the overall peat resource that has been subject to management. In Scotland, $24 \%$ of the land area is covered by peatlands (i.e. peat soils of more than $50 \mathrm{~cm}$ peat depth, Chapman et al., 2009). A sizeable proportion of the UK raised and blanket bogs were afforested in the 1970s and 1980s and the discussion of how to manage these forests or whether to restore such sites to peatland habitat brings with it potential implications for national accounting of GHG emissions from the land use sector. We recognise the need for measurements of GHG fluxes from afforested peatlands, especially in relation to emissions from restored peatlands, towards which this publication has made a positive contribution. However, we believe that the conclusions drawn by Yamulki et al. (2013) regarding the relative GHG balance of their different study sites are not robust. Here, we highlight two key areas in which we believe that their measurements, calculations and interpretation may be open to question, and in one case are demonstrably incorrect. In order to put the observed fluxes into context for further evaluation, it would be useful if further details about the study sites could be provided so that this work can contribute more 
effectively to future literature-based meta-analyses of the effects of different land use on GHG emissions from peatlands. We hope this comment also serves to open a wider discussion of the changing long-term dynamics of GHG emissions with land-use transitions, such as afforestation or restoration practices, on peatlands.

Firstly, in order to aid the reader, we briefly re-iterate the current consensus on how net ecosystem carbon balances (NECB) are calculated. Until fairly recently, many authors implicitly or explicitly assumed that a measure defined as net ecosystem production (NEP) equals the net rate of carbon accumulation and hence the NECB of an ecosystem (see Lovett et al., 2006; Chapin et al., 2006). Net ecosystem production (NEP) was first defined by Woodwell and Whittaker (1968) as the differential between the gross primary production (GPP, the gross photosynthetic uptake of carbon) and the net ecosystem respiratory loss of carbon $\left(R_{\text {eco }}\right)$. A complete NECB, however, contains further terms such as (1) any imports of carbon, for example through animal faeces or other movement, deposition from rain or other sources such as soot, which are collectively termed imported $\mathrm{C}\left(I_{\mathrm{C}}\right)$; and (2) any exports of carbon $\left(E_{\mathrm{C}}\right)$, for example through formation of dissolved organic carbon (DOC), erosion of particulate organic carbon (POC), and subsequent export of both along watercourses, Aeolian erosion, grazing and subsequent animal movement; and (3) large disturbances that involve non-biological oxidation such as biomass harvest for fuel as well as (wild) fires $\left(\mathrm{Ox}_{\mathrm{nb}}\right)$. Hence,

$\mathrm{NECB}=\mathrm{NEP}+$ imported organic $\mathrm{C}\left(I_{\mathrm{C}}\right)-$ exported organic carbon $\left(E_{\mathrm{C}}\right)$ - non-biological oxidation of $\mathrm{C}\left(\mathrm{Ox}_{\mathrm{nb}}\right)$.

The main components that are most commonly measured in ecosystem carbon budgets are the terms of NEP, namely, gross primary production (GPP) and ecosystem respiration $\left(R_{\text {eco }}\right)$.

$\mathrm{NEP}=\mathrm{GPP}-R_{\mathrm{eco}}$

$R_{\text {eco }}$ is the sum of all autotrophic and heterotrophic respiration ( $R_{\mathrm{a}}$ and $R_{\mathrm{h}}$, respectively) in an ecosystem. Gross primary production is not generally directly measured at the whole ecosystem level, as it requires measurements of the uptake of $\mathrm{CO}_{2}$ into photosynthetic tissue (e.g. leaves) followed by upscaling with measurements of the total photosynthetic tissue volume or mass. Rather, the net primary production (NPP), which is the difference between GPP and $R_{\mathrm{a}}$, is generally monitored (Woodwell and Whittaker, 1968). This includes the net production of above-ground, easily monitored biomass (e.g. leaves, stems, branches, flowers, seeds, leachable organics) and also net below-ground production (e.g. roots, root exudation, export to symbionts) as summarised by Clark et al. (2001).

$\mathrm{NPP}=\mathrm{GPP}-R_{\mathrm{a}}$
Autotrophic respiration in forest and peatland ecosystems include the respiration of any living component of plant biomass, such as leaves, needles, roots, and stems. If NPP is the primary measured variable, the missing part to calculate $\mathrm{NEP}$ is heterotrophic respiration $\left(R_{\mathrm{h}}\right)$ as NEP $=\mathrm{NPP}-R_{\mathrm{h}}$.

Within the inputs and outputs of gaseous carbon compounds, there are a large number to consider. Whilst photosynthetic activity fixes only $\mathrm{CO}_{2}$, other gaseous organic carbon compounds such as carbon monoxide and methane can similarly be fixed in oxidising, microbially mediated, reactions at the soil surface. Similarly, the respiratory losses of organic carbon do not only include $\mathrm{CO}_{2}$ and $\mathrm{CH}_{4}$, but also a wide array of other volatile organic compounds (VOC) (e.g. Kesselmeier and Staudt, 1999; Faubert et al., 2010). Net ecosystem exchange (NEE), a term used by atmospheric scientists and generally defined as the instantaneous net flux of $\mathrm{CO}_{2}$ to the atmosphere (i.e. always opposite in sign to NEP, and negative if net $\mathrm{CO}_{2}$ sequestering), can be relatively easily approximated with measurements obtained via eddy covariance or chamber-based techniques. However, this relative ease to measure one of the major fluxes in the NECB has led to many reports where authors have taken NEE to equal (-)NEP (i.e. essentially assuming the gaseous ecosystem carbon losses to include only $\mathrm{CO}_{2}$ ). In addition, NEE is generally measured over very short time periods ("instantaneous"), whereas NEP is generally calculated over a growing season or year. In short, the component terms of a full NECB are very numerous and can be rather laborious to determine. In practice, most published NECB concentrate on those component parts deemed the most significant. However, as the difference between a functional peatland and a non-functional one is determined by only a very small imbalance between inputs and outputs, as the long-term accumulation rates of near-natural peatlands within the last millennium are of the order of ca. $10-37 \mathrm{~g} \mathrm{C} \mathrm{m}^{-2} \mathrm{yr}^{-1}$ (Yu et al., 2012; Charman et al., 2013), it is important that none of the major fluxes are omitted.

\subsection{Static chamber methodology}

Yamulki and co-authors present data from biweekly measurements of soil-derived trace gas emissions $\left(\mathrm{CO}_{2}\right.$, $\mathrm{CH}_{4}$ and $\mathrm{N}_{2} \mathrm{O}$ ) using static, opaque (dark), chamber $(0.4 \mathrm{~m} \times 0.4 \mathrm{~m} \times 0.25 \mathrm{~m})$ measurements on their four experimental treatments. These included 0.5 hectare replicated plots of drained and planted (45 yr old trees) areas (DP), undrained and planted areas of the same stand age (uDP), and an undrained/unplanted control on the same site (uDuP). In addition, a number of pseudo-replicated measurements on a single $20 \mathrm{~m} \times 30 \mathrm{~m}$ ( $0.06 \mathrm{ha})$ unmanaged plot were made within a nearby $(7.5 \mathrm{~km}$ east $)$ peatland. This plot was located within a previous plantation that was felled in 1998 and subsequently restored to active raised bog by blocking the drains. The abbreviation used for this plot in the text ( $n$ pris) suggests that this site is in its original, 


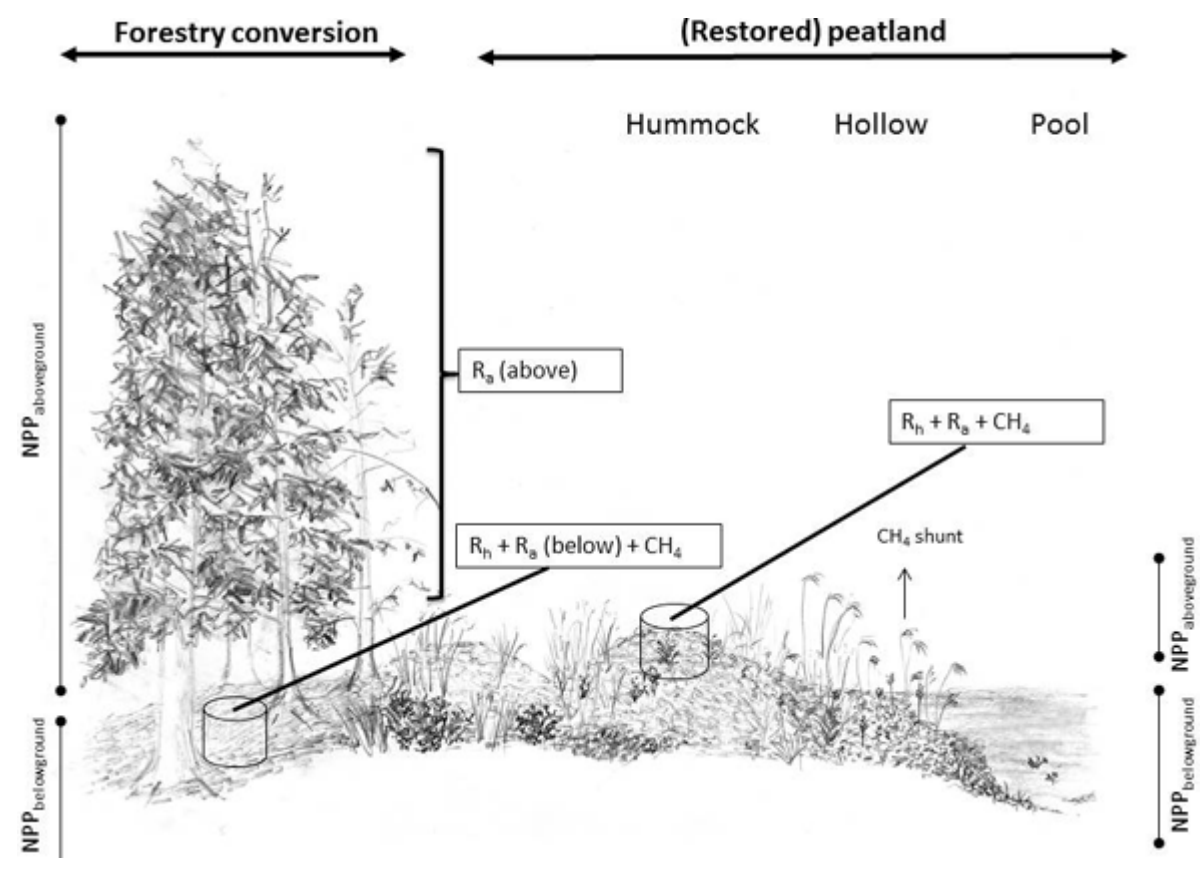

Fig. 1. Simplified drawing of the difference in captured gas fluxes with small chamber-based GHG measurements in forestry (left) or (restored) peatland sites (right). Chamber height, volume and location determine which of the net fluxes are included or excluded in each of the two settings. In the peatland setting, the opaque chamber dimensions of Yamulki et al. (2013) allow for inclusion of both the entire autotrophic and heterotrophic respiration pools $\left(R_{\mathrm{a}}\right.$ and $R_{\mathrm{h}}$, respectively) and hence represent dark net ecosystem respiration $\left(R_{\mathrm{eco}-\mathrm{dark}}\right)$. Use of clear chambers in such settings can also capture GPP (gross primary productivity) as well as $R_{\text {eco-light }}$. A reasonable estimate of net ecosystem productivity (NEP) could be achieved by using reliable GPP and a modelled $R_{\text {eco }}$ measured throughout diurnal and seasonal cycles. Net methane fluxes $\left(\mathrm{CH}_{4}\right)$ are also included. Ensuring sufficient coverage of peatland microtopography (e.g. hummocks, hollows, and pools) however is required as, for example, aerenchymatous species in hollows may act as $\mathrm{CH}_{4}$ shunts. In the forest setting, use of the same chambers will include $R_{\mathrm{h}}$ but only the below-ground components of $R_{\mathrm{a}}$, as the stems, branches and needles of the tree biomass ( $R_{\mathrm{a}}$ ) are not included within the chamber. This means that, for a reasonable estimate of NEP to be established, at the very least the aboveground component of $R_{\mathrm{a}}$ would require to be measured, along with GPP. Often, however, GPP is not directly measured in forest ecosystems and instead some components of NPP are measured by stock assessments of aboveground biomass, e.g. stem, branch and needle biomass, coupled with estimates of below-ground NPP. In addition, in forest stands, the chambers will include net $\mathrm{CH}_{4}$ fluxes. The other components of NECB, for example the net exported fluxes of aqueous carbon such as DOC and POC are often also substantial and some, such as oxidised carbon export through fires or off site biomass combustion/decay, are rarely investigated (see main text).

near-pristine condition, implying minimal anthropogenic disturbance, which is most certainly not the case. The measured $\mathrm{CO}_{2}$ flux was "derived from aerobic and anaerobic decomposition processes, respiration of other soil organisms, total dark respiration of ground vegetation and root respiration of trees". The statement by the authors as re-iterated above, in combination with the size of the chambers, implies that the measured respiratory fluxes on the unplanted sites (uDuP and $n$ pris) included autotrophic respiration $\left(R_{\mathrm{a}}\right)$ from the above-ground vegetation (Sphagnum moss and other bog vegetation) and hence represent net ecosystem dark respiration $\left(R_{\text {eco-dark }}\right)$ (Fig. 1). Net ecosystem respiration can vary substantially between daytime and night-time and full GHG balances usually require measurements taken over the full diurnal range (e.g. Laine et al., 2007). On the other hand, the fluxes from the forested sites must have excluded $R_{\mathrm{a}}$ from the canopy and other above-ground biomass of the trees (Fig. 1). Ground vegetation below the tree canopy in these forestry plantations is typically minimal. While this is to some extent an unavoidable logistical issue, the implication is that the flux measured in the planted plots (DP and uDP) represents only soil respiration $\left(R_{\text {soil }}\right)$. This term includes all of the heterotrophic components from litter and soil organic matter decomposition $\left(R_{\mathrm{h}}\right)$ but only some of the $R_{\mathrm{a}}$ components, because only root respiration, but not aboveground autotrophic respiration, is included in the measurements (Fig. 1). As a minor aside, the chamber size would have excluded major roots and also the depth of collar insertion $(3 \mathrm{~cm})$ may have led to some root severance, thus underrepresenting root respiration. The likely omission of $R_{\mathrm{a}}$ aboveground is reflected in the reported annual fluxes from the planted sites, which are much lower than those from the unplanted sites. They report 1.61 and $1.22 \mathrm{~kg} \mathrm{CO}_{2} \mathrm{~m}^{-2} \mathrm{yr}^{-1}$ from the drained and undrained planted sites, respectively, vs. 2.58 and $1.84 \mathrm{~kg} \mathrm{CO}_{2} \mathrm{~m}^{-2} \mathrm{yr}^{-1}$ in the neither drained nor planted peatland block and the nearby restored peatland 
area. In short, the presented data from the afforested sites, lacking the autotrophic flux from above-ground tree biomass, give an estimate of the total soil $\mathrm{CO}_{2}$ flux $\left(R_{\text {soil }}\right)$, whereas the figures presented from the unplanted bog sites represent $R_{\text {eco-dark }}$. The data presented in Tables 3 and 4 in Yamulki et al. (2013) therefore represent an erroneous comparison between $R_{\text {eco-dark }}$ from the uDuP and $n$ pris sites and $R_{\text {soil }}$ from the DP and uDP. This introduces a bias, as is discussed further below.

\subsection{Calculations of net $\mathrm{CO}_{2}$ fluxes}

The second issue we identify relates to the calculation of both the "net ecosystem $\mathrm{CO}_{2}$ exchange" and the overall "net GHG flux" (Table 4) for their study sites. Here, we believe that the calculation of net GHG flux for their "near-pristine" site ( $n$ pris) is demonstrably incorrect. Yamulki and co-workers measured $R_{\text {eco }}$ in the unplanted sites. Thus, the missing term in the estimation of NEE- $\mathrm{CO}_{2}$ for these sites is GPP. However, for the unplanted sites, Yamulki and co-workers used literature values of NEE from other semi-natural bogs in place of GPP as their input term (see Table 4 in Yamulki et al. (2013)). Although they correctly label this term "net ecosystem $\mathrm{CO}_{2}$ exchange" in their Table 4 , they added the sum of all soil-derived trace gas emissions in terms of $\mathrm{CO}_{2}$ equivalents $\left(\mathrm{CO}_{2} \mathrm{e}\right)$ ("total soil GHG emission", $=R_{\text {eco }}$ of all $3 \mathrm{GHGs}$ ) to this value to calculate the "net GHG flux". We have clarified the values presented in Table 4 against the cited literature to confirm that these indeed represent net ecosystem $\mathrm{CO}_{2}$ exchange. The values are based on chamber (Billett et al., 2004) and eddy covariance measurements at Auchencorth Moss (Dinsmore et al., 2010), both incorporated into the cited review of Billett et al. (2010). Hence, $R_{\text {eco }}$ was effectively double-counted in the "net GHG flux" calculations for the $n$ pris site, leading to the incorrect inclusion of a $\mathrm{CO}_{2}$ emission of $1821 \mathrm{~g} \mathrm{CO}_{2} \mathrm{e} \mathrm{m}^{-2} \mathrm{yr}^{-1}$ in the total estimated GHG emission of $1993-2303 \mathrm{~g} \mathrm{CO}_{2} \mathrm{e} \mathrm{m}^{-2} \mathrm{yr}^{-1}$ for this site. Correctly omitting this flux would put the net GHG flux figure closer to a likely small net GHG source in $\mathrm{CO}_{2}$ equivalents, although formally estimating a balance on the basis of the data presented would not be advisable with NEE data from a hydrologically very different site. For the purpose of illustration only, however, in the most climatically similar year in relation to the Yamulki study, the Dinsmore et al. (2010) figures for Auchencorth Moss in 20072008 reported a net ecosystem exchange of $\mathrm{CO}_{2}$ of $-420 \mathrm{~g}$ $\mathrm{CO}_{2} \mathrm{e} \mathrm{m}^{-2} \mathrm{yr}^{-1}$. Adding the observed methane and nitrous oxide losses to this assumed net fixation of $\mathrm{CO}_{2}$ would result in a net GHG flux of $172 \mathrm{~g} \mathrm{CO}_{2} \mathrm{e} \mathrm{m}^{-2} \mathrm{yr}^{-1}$ rather than the stated (10 times higher) range. For the restored site of Yamulki et al., if this is as "near-pristine" as the authors suggest, we would have expected it to be similarly close to equilibrium, at least in terms of the net carbon balance. If the reported rate of $\mathrm{CO}_{2}$ emission were correct (a massive net loss of 19.9 to 23 tonnes of $\mathrm{CO}_{2} \mathrm{e} \mathrm{ha}^{-1} \mathrm{yr}^{-1}$ ), we would ex- pect this site to be subject to subsidence approaching the 1$2 \mathrm{~cm} \mathrm{yr}^{-1}$ observed in peatlands drained for intensive arable use. Of course, a more ideal scenario would have been the inclusion of measured GPP data for the $n$ pris site, such that the $R_{\text {eco }}-\mathrm{CO}_{2}$ loss could be balanced against a measure of GPP on site. Previous studies performed on near-natural peatlands (e.g. Billett et al., 2010; Koehler et al., 2011) consistently suggest that these systems are net $\mathrm{CO}_{2}$ sinks. Following the inclusion of $\mathrm{CH}_{4}$ and $\mathrm{N}_{2} \mathrm{O}$ emissions, they may be either small net GHG sinks or small net GHG sources (e.g. Billett et al., 2010; Koehler et al., 2011), although the recent review of Yu (2012) concluded that the majority of natural peatlands have a net cooling effect on a $100 \mathrm{yr}$ time horizon. The $n$ pris site in Yamulki et al. (2013) of course is not a truly near-pristine site. As stated, this is a very small plot that had not been drained or planted, but is located within a formerly afforested plot, which had subsequently been restored by felling the trees 10 years prior to the start of the GHG flux measurements. The implications of this recent management event on estimates of the likely GHG balance will be discussed further below, but first we examine the calculations of the net GHG flux for the planted sites.

For the planted sites, Yamulki et al. use an estimated value of "net ecosystem $\mathrm{CO}_{2}$ exchange" in Table 4 that is based on total tree biomass calculated from whole site tree mensuration data and to which they add their combined soil-derived trace gas emissions ("total soil GHG emissions") to determine the net GHG flux for these sites. We challenge that the "net ecosystem $\mathrm{CO}_{2}$ exchange" value presented here is in fact a representation of net primary productivity (NPP): GPP minus the amount of carbon respired by the trees through autotrophic respiration $\left(R_{\mathrm{a}}\right)$. Firstly, the authors state that it "does not include accumulation of leaf, branch and root litter", although it presumably does include living root and needle biomass. Hence, this figure may be an underestimate of NPP and likely ranges of annual litter production could perhaps have been provided as the soil-based GHG fluxes would have included respiration of some of this litter pool as well as turnover of more decomposed soil organic matter. To this NPP value, the total sum of all soil-based trace gas losses are added to calculate the net GHG flux. Although this would seem a valid approach, the measured soil $\mathrm{CO}_{2}$ efflux included autotrophic respiration from the tree roots. In other words, some components of the net respiratory losses are double counted in the net GHG flux calculation. The authors do state that this calculation "is slightly overestimating net $\mathrm{CO}_{2}$ losses as tree root respiration is included". However, the proportional input from autotrophic respiration to the soil respiratory fluxes can be up to $50 \%$ in temperate coniferous forest ecosystems (Subke et al., 2006; Bond-Lamberty et al., 2004), so this is not an inconsiderable flux. Some estimates of the relative contributions of $R_{\mathrm{a}}$ and $R_{\mathrm{h}}$ to the overall $R_{\mathrm{eco}}$ in afforested peatlands may be found in, e.g. Mäkiranta et al. (2010) where a partition of such fluxes was presented. Therefore, depending on the proportion of root autotrophic 
respiration to the overall $R_{\text {soil }}$, and the fate of any annual litter inputs compared to the contribution of litter decomposition to $R_{\mathrm{h}}$, the net GHG flux at the afforested sites may be significantly different to the value calculated in Table 4 and could be substantially lower.

One might also question the use of a value of NPP derived from the linear interpolation of biomass accumulation as forest growth models generally adopt a more sigmoidal shape and as such the productivity and carbon sink strength of an older forest may in theory be lower at the time of the measurements than the value presented here. The authors also state, citing the work of Minkkinen and Laine (1998), that productivity in the drained and afforested area is likely to have been higher than in the undrained site, yet this is not taken into consideration when calculating the net ecosystem GHG budget. In any of the above scenarios, the net GHG flux estimates for the planted sites are also likely to be compromised.

We welcome the points of further clarification received in response to our interactive comment from the authors (Yamulki, 2013) as to the assumptions made in the calculation of the net ecosystem $\mathrm{CO}_{2}$ exchange and net GHG flux at these sites. The highlighted calculation errors markedly alter the final conclusions of the paper regarding the relative GHG balance of forested and unforested peatlands as the $n$ pris site, although still a net source in $\mathrm{CO}_{2}$ equivalents, is likely to be a net source of much smaller magnitude than presented, and the afforested sites, for entirely different reasons, may also be a much smaller net source. Based on the data presented in the paper, however, it is impossible to establish the likely net GHG flux at any of the sites correctly, and hence a comparison between the planted and $n$ pris sites should not be a part of the discussion of the data.

\subsection{Methane measurements}

Our final area of concern in relation to the GHG balances reported for the sites at Flanders Moss is the significant emission of methane $\left(22.6 \mathrm{~g} \mathrm{CH}_{4} \mathrm{~m}^{-2} \mathrm{yr}^{-1}\right)$ reported from the restored ( $n$ pris) site. This exceeds the range given by Levy et al. (2012) for methane emissions from a wide range of UK soils, including many peatlands, which tend to have values at the upper end of the -0.15 to $13.8 \mathrm{~g} \mathrm{~m}^{-2} \mathrm{yr}^{-1}$ range observed. In the recent Couwenberg and Fritz (2012) synthesis, the highest emissions published from temperate raised bogs with plant communities including aerenchymatous species (which can transport methane through their roots and stems) were approx. $50 \mathrm{~g} \mathrm{CH}_{4} \mathrm{~m}^{-2} \mathrm{yr}^{-1}$, as opposed to $25 \mathrm{~g} \mathrm{CH}_{4} \mathrm{~m}^{-2} \mathrm{yr}^{-1}$ where no aerenchymatous plants were present. While the methane emissions published in this paper appear reasonable in this context, it does indicate that they are in the upper range of previously published work or that there would have to be a significant contribution through plant mediated transport, an issue that is not considered in this paper as a potential contributing factor. The high val- ues observed may also represent an artefact of the location of this small, unplanted, 0.06 ha plot, in the middle of a previous plantation forest. Often such areas were never planted as they were too wet even following drainage and the authors state that the site "became extremely wet" following the restoration activities surrounding it. The chamber size suggests that the measurements at this site may not represent an accurate assessment of the heterogeneity of these ecosystems, which are comprised of a wider suite of microform features (e.g. hummocks, hollows, lawns and pools). These need to be considered when making ecosystem scale GHG assessments. It would be advantageous to report the vegetation characteristics (e.g. presence of aerenchymatous species) of sites where chamber measurements are taken, as well as the location of chambers, in any publication of GHG fluxes on peatlands as this can improve scientific consensus on the observed trace gas emissions in relation to peatland microforms. Yamulki (2013) gives further information, for example, on the cover of aerenchymatous species and particularly the very interesting site history in their reply to our interactive comment. This suggests that the $n$ pris site was distinguishable from the surrounding peatland before planting began and "may not be representative of other areas, restored or pristine", which will be of great use for future literaturebased meta-analyses.

\section{Towards assessments of GHG benefits of afforestation or restoration of peatlands}

We believe that any realistic assessment of the GHG benefits or costs of afforestation or restoration of peatlands needs to take into account the long-term, whole life cycle, carbon budget. To establish the carbon sink strength of nearnatural peatlands, $\mathrm{Yu}$ (2012) conducted a meta-analysis of full $\mathrm{C}$ budget data collected for a minimum of two and maximum of six yr at five peatland sites in the Northern Hemisphere and compared these with long-term carbon accumulation rates. The study showed that only one of the five sites (a minerotrophic site) exhibited methane emissions that, in carbon dioxide equivalents, would negate the strong net fixation through net ecosystem exchange of carbon dioxide. The geographically closest of the cases in Yu (2012) to the sites used by Yamulki et al., is Auchencorth Moss, which is the site they derive some of their literature values from. As referred to earlier, in the most climatically similar year in relation to the Yamulki study, the Dinsmore et al. (2010) figures for Auchencorth Moss in 2007-2008 reported a net ecosystem exchange of $\mathrm{CO}_{2}$ of $-420 \mathrm{~g} \mathrm{CO}_{2} \mathrm{e} \mathrm{m}^{-2} \mathrm{yr}^{-1}$. This NEE value, plus a net loss of $9.75-11.5 \mathrm{~g}$ of $\mathrm{CO}_{2} \mathrm{e} \mathrm{m}^{-2} \mathrm{yr}^{-1}$ as methane and similar values for $\mathrm{N}_{2} \mathrm{O}$ emissions, together with the other relevant carbon budgets such as aqueous losses from the system, still resulted in a net carbon sink as well as net global cooling effect for the whole Auchencorth site (Drewer et al., 2010). The Auchencorth site, however, might not represent 
a suitable comparison to the Flanders Moss sites in Yamulki et al. (2013), as it is on relatively shallow peat and has been affected by past drainage and nearby peat extraction, which has lowered the water table at this site. Overall, though, the sequestering function of an established peatland, as in any biological system, is likely to be dependent on its relative maturity. Productivity in forest ecosystems is highest in the initial growth phase and declines with the stand age of forests. Reports of GHG flux measurements from restored peatland areas suggest strong growth of the recolonizing vegetation, which can lead to NEE in excess of that observed in natural peatlands in their mature phases (Bortoluzzi et al., 2006; Samaritani et al., 2011).

Restored peatlands, especially in the early phases of recovery, will inevitably present a different carbon budget to pristine or near-natural sites, and this carbon budget will be a function of the initial condition of the peatland prior to restoration, the hydrological conditions achieved through restoration and the stage of the restoration trajectory. The limited studies published to date on this topic have included examples of previously industrially harvested peatlands (Yli-Petays et al., 2007) as well as peatlands subjected to limited disturbance through domestic peat cutting or moderate drainage (Bortoluzzi et al., 2006; Samaritani et al., 2011). Yli-Petays et al. (2007) reported losses of up to $38.4 \mathrm{~g} \mathrm{CH}_{4} \mathrm{~m}^{-2} \mathrm{yr}^{-1}$ in a rewetted (periodically flooded) poor fen peatland $50 \mathrm{yr}$ after abandonment following mechanical peat extraction. These high methane emissions, together with a net ecosystem $\mathrm{CO}_{2}$ exchange of between 30 $83 \mathrm{~g} \mathrm{C} \mathrm{m}^{-2} \mathrm{yr}^{-1}$ due to the still patchy vegetation, suggested that these sites were still strong net $\mathrm{C}$ sources despite restoration management. In contrast, Bortoluzzi et al. (2006) and Samaritani et al. (2011) reported potential strong net GHG sinks in peatlands recovering from less severe damage. Bortoluzzi et al. (2006) observed $\mathrm{CH}_{4}$ emissions in the range of $6-130 \mathrm{CO}_{2} \mathrm{e} \mathrm{m}^{-2} \mathrm{yr}^{-1}$ in vegetated areas in a site last cut and drained $20 \mathrm{yr}$ previously, but these emissions were more than offset by a NEE-CO $\mathrm{CO}_{2}$ of -200 to $-600 \mathrm{~g} \mathrm{CO}_{2} \mathrm{~m}^{-2} \mathrm{yr}^{-1}$. The exceptions were bare patches where $\mathrm{CH}_{4}$ fluxes outweighed NEE- $\mathrm{CO}_{2}$ due to a combination of lack of vegetation and a high water table. Samaritani et al. (2011) reported their early stage restoration site ( $29 \mathrm{yr}$ since the last disturbance) to be a net source of $40 \mathrm{~g} \mathrm{CO}_{2} \mathrm{e} \mathrm{m}^{-2} \mathrm{yr}^{-1}$, compounded by an additional loss of at least $46 \mathrm{~g} \mathrm{CO}_{2} \mathrm{e} \mathrm{m}^{-2} \mathrm{yr}^{-1}$ as methane. However, both of their older restoration sites were net GHG sinks, with observed balances of $-220 \mathrm{~g} \mathrm{CO}_{2} \mathrm{~m}^{-2} \mathrm{yr}^{-1}$, slightly offset by $57 \mathrm{~g} \mathrm{CO}_{2} \mathrm{e} \mathrm{m}^{-2} \mathrm{yr}^{-1}$ as methane in a $42 \mathrm{yr}$ old site, and $-209 \mathrm{~g} \mathrm{CO}_{2} \mathrm{~m}^{-2} \mathrm{yr}^{-1}$ partially offset by $150 \mathrm{~g}$ $\mathrm{CO}_{2} \mathrm{e} \mathrm{m}^{-2} \mathrm{yr}^{-1}$ as methane in a $51 \mathrm{yr}$ old site. In both studies, the site hydrology was relatively stable, with few flooding events. The long-term, net radiative forcing effect of methane emissions is much more complex than standard global warming calculations alone can show. Methane emitted to the atmosphere, despite having higher radiative efficiency than carbon dioxide per mass unit, has a shorter atmospheric lifes- pan. Frolking et al. (2006) pointed out that the net radiative balance is dependent on the long-term mol: mol ratio of $\mathrm{CO}_{2}: \mathrm{CH}_{4}$ emitted as well as the long-term dynamics of this emissions ratio. The atmospheric mixture of these gases, and hence the net radiative forcing effect in the atmosphere, is a combination of their relative potency and lifespan. Hence, the effects of current methane emissions decline over time as their atmospheric concentration drops through oxidative processes.

There are very few examples of GHG fluxes of afforested peatlands where all the component terms have been measured concurrently, or over a longer time frame. Whole site NEE reports from a naturally afforested peatland in Finland (subjected to additional drainage 34 years previously to aid timber growth) concluded that the site, at that point in its life cycle, acted as a net carbon sink of between $870-1000 \mathrm{~g}$ $\mathrm{CO}_{2} \mathrm{~m}^{-2} \mathrm{yr}^{-1}$, of which the tree biomass accumulation accounted for 585-645 $\mathrm{g} \mathrm{CO}_{2} \mathrm{~m}^{-2} \mathrm{yr}^{-1}$ (Ojanen et al., 2012). Hence, in that example, the relatively sparse tree density as well as the remaining peatland vegetation cover both contributed to net $\mathrm{C}$ sequestration. In other peatland forest sites, such as reported by Lohila et al. (2007), where drainage was more effective and active planting took place (resulting in greater tree density) a net annual loss of $\mathrm{CO}_{2}$ from the system was reported due to large soil respiratory losses. Their study site was a $30 \mathrm{yr}$ old Sitka spruce plantation, which, over the course of a year, only served as a net carbon sink for $\mathrm{CO}_{2}$ during warm and dry spells in the summer months. On cold or damp summer days, the system was a net source, with net soil respiration emissions in the same range as reported by Yamulki et al. (2013). In a UK setting, the only comparable study is Hargreaves et al. (2003), who studied NEE-CO using eddy covariance techniques on a variety of peatlands ranging from near-natural (Auchencorth Moss) to sites with $26 \mathrm{yr}$ old plantation forestry stands. They reported a moderate net $\mathrm{CO}_{2}$ sink within the same range as reported by Billett et al. (2004) at the control (Auchencorth Moss) site, followed by net emissions after site preparations for two years. A net uptake in excess of that at Auchencorth Moss was observed for all afforested sites of more than $4 \mathrm{yr}$ of growth up to $26 \mathrm{yr}$ old stands. However, most of the reported fluxes were based on extrapolations from periods of 3-4 weeks, based on the diurnal variation observed at the Auchencorth Moss site, where data were collected over a year and 9 months.

On a greater temporal scale, any plantation forest will eventually be harvested and the $\mathrm{C}$ sequestered in tree biomass will be effectively lost from the system, although longevity off-site is dependent on the timber products derived and the rates of decomposition of remaining stems, brash, stumps and roots. In addition, the disturbance effect from harvesting and replanting will also release a large gaseous and dissolved C pulse. The Yamulki et al. (2013) study contrasted drained/undrained sites in a plantation forest on peat soil at a late growth phase (i.e. at the end of the phase where $\mathrm{C}$ is strongly sequestered in tree biomass) with sites that were 
either likely to be confounded by the drying effect of nearby forestry, or were part of a restoration site recovering from a relatively recent, large disturbance event, through the felling of the surrounding plantation $10 \mathrm{yr}$ before the GHG flux measurements. The comparison of "snapshot" images at different times in the systems' growth cycle, regardless of any inherent bias in the calculations, can be problematic particularly when extrapolating to wider areas or use as a policy-development tool. To give an accurate assessment, such comparisons need to be made on the basis of the total GHG budget over, or normalised for, the whole life cycle of plantation forestry versus restored peatlands. The current knowledge base in relation to the ability of restored peatlands to eventually become net $\mathrm{C}$ sequestering ecosystems again is insufficient, yet our best understanding is that natural peatlands predominantly act as net cooling ecosystems, even under current climatic constraints (Frolking et al., 2011; Yu, 2012). As long as restoration can achieve a reversion to a "near-natural" state, the preservation of carbon sequestered in peatland ecosystems is likely to represent a more effective carbon store when compared to plantation forests over the very long-term $(>100 \mathrm{yr})$.

\section{Summary}

Yamulki et al. (2013) present a detailed, comprehensive set of measurements of GHG fluxes from peatland sites subject to contrasting management. Such measurements are sparse at both a national and a global scale, and are urgently needed to support policy on peatland management for climate mitigation, and in a wider ecosystem services context. We believe that the conclusion presented by Yamulki et al. (2013) that the total net GHG emission of a restored peat bog exceeds that of an adjacent afforested site at Flanders Moss, is erroneous and based on a number of flawed assumptions made during the analysis of their results. Although Yamulki et al. (2013) did not extrapolate their findings to a wider landscape or political context, in an era where it has become a necessity to reduce global GHG emissions, the scientific knowledge base that helps to answer the question of where and how to achieve the national emissions reductions targets must not present confused scenarios. We contacted the authors of the publication with a previous draft of this Comment, to avoid factual errors on our part and to facilitate an open discussion. Yamulki and co-workers have subsequently replied to this discussion with a number of clarifications on their original publication as well as additional information that will be of high value to future studies of net ecosystem carbon balances in peatlands, including those with alternative land uses (Yamulki, 2013).
Acknowledgements. We would like to thank two anonymous reviewers whose comments helped to improve this manuscript.

Edited by: J.-A. Subke

\section{References}

Billett, M. F., Palmer, S. M., Hope, D., Deacon, C., StoretonWest, R., Hargreaves, K. J., Flechard, C., and Fowler, D.: Linking land-atmosphere stream carbon fluxes in a lowland peatland system, Glob. Biogeochem. Cycl., 18, GB1024, doi:10.1029/2003GB002058, 2004.

Billett, M. F., Charman, D. J., Clark, J. M, Evans, C. D., Evans, M. G., Ostle, N. J., Worrall, F., Burden, A., Dinsmore, K. J., Jones, T., McNamara, N. P., Parry, L., Rowson, J. G., and Rose, R.: Carbon balance of UK peatlands: current state of knowledge and future research challenges, Clim. Res., 45, 13-29, 2010.

Bond-Lamberty, B., Wang, C., and Gower, S. T.: A global relationship between the heterotrophic and autotrophic components of soil respiration? Global Change Biology, 10, 1756-1766, 2004.

Bortoluzzi, E., Epron, D., Siegenthaler, A., Gilbert, D., and Buttler, A.: Carbon balance of a European mountain bog at contrasting stages of regeneration, New Phyt., 172, 708-718, 2006.

Chapin III, F. S., Woodwell, G. M., Randerson, J. T., Rastetter, E. B., Lovett, G. M., Baldocchi, D. D., Clark, D. A., Harmon, M. E., Schimel, D. S., Valentini, R. Wirth, C., Aber, J. D., Cole, J. J., Goulden, M. L., Harden, J. W., Heimann, M., Howarth, R. W., Matson, P. A., McGuire, A. D., Melillo, J. M., Mooney, H. A., Neff, J. C., Houghton, R. A., Pace, M. L., Ryan, M. G., Running, S. W., Sala, O. E., Schlesinger, W. H., and Schulze, E.-D.: Reconciling carbon-cycle concepts, terminology and methods, Ecosystems, 9, 1041-1050, 2006.

Chapman, S.J., Bell, J., Donnelly, D., and Lilly, A.: Carbon stocks in Scottish peatlands. Soil Use Manag., 25, 105-112, 2009.

Charman, D. J., Beilman, D. W., Blaauw, M., Booth, R. K., Brewer, S., Chambers, F. M., Christen, J. A., Gallego-Sala, A., Harrison, S. P., Hughes, P. D. M., Jackson, S. T., Korhola, A., Mauquoy, D., Mitchell, F. J. G., Prentice, I. C., van der Linden, M., De Vleeschouwer, F., Yu, Z. C., Alm, J., Bauer, I. E., Corish, Y. M. C., Garneau, M., Hohl, V., Huang, Y., Karofeld, E., Le Roux, G., Loisel, J., Moschen, R., Nichols, J. E., Nieminen, T. M., MacDonald, G. M., Phadtare, N. R., Rausch, N., Sillasoo, Ü., Swindles, G. T., Tuittila, E.-S., Ukonmaanaho, L., Väliranta, M., van Bellen, S., van Geel, B., Vitt, D. H., and Zhao, Y.: Climaterelated changes in peatland carbon accumulation during the last millennium, Biogeosciences, 10, 929-944, doi:10.5194/bg-10929-2013, 2013.

Clark, D. A., Brown, S., Kicklighter, D. W., Chambers, J. Q., Thomlinson, J. R. and Ni, J.: Measuring net primary production in forests: concepts and field methods. Ecol. Applic., 11, 356-370, 2001.

Couwenberg, J. and Fritz, C.: Towards developing IPCC methane "emission factors" for peatlands (organic soils), Mires. Peat., 10, 1-17, 2012.

Dinsmore, K. J., Billett, F. M., Skiba, U. M., Rees, R. M., Drewer, J., and Helfter, C.: Role of the aquatic pathway in the carbon and greenhouse gas budgets of a peatland catchment, Glob. Change Biol., 16, 2750-2762, doi:10.1111/j.1365-2486.2009.02119.x, 2010. 
Drewer, J., Lohila, A., Aurela, M., Laurila, T., Minkkinen, K., Penttilä, T., Dinsmore, K. J., McKenzie, R. M., Helfter, C., Flechard, C., Sutton, M. A. and Skiba, U. M.: Comparison of greenhouse gas fluxes and nitrogen budgets from an ombrotrophic bog in Scotland and a minerotrophic sedge fen in Finland, Eur. J. Soil Sci., 61, 640-640. 2010.

Faubert, P., Tiiva, P., Rinnan, A., Räsänen, J., Holopainen, J., Holopainen, T., Kyrö, E., and Rinnan, R.: Non-methane biogenic volatile organic compound emissions from a subarctic peatland under enhanced UV-B radiation, Ecosystems, 13, 860-873, 2010.

Frolking, S., Roulet, N., and Fuglestvedt, J.: How northern peatlands influence the Earth's radiative budget: Sustained methane emissions versus sustained carbon sequestration, J. Geophys. Res., 111, G01008, doi:10.1029/2005JG000091, 2006.

Frolking, S., Talbot, J., Jones, M.C., Treat, C.C., Boone Kauffman, J., Tuittila, E.-S., and Roulet, N.: Peatlands in the Earth's 21st century climate system, Environ. Rev., 19, 371-396, 2011.

Hargreaves, K., Milne, R., and Cannell, M.: Carbon balance of afforested peatland in Scotland, Forestry, 76, 299-317, 2003.

Kesselmeier, J. and Staudt, M.: Biogenic volatile organic compounds (VOC): an overview on emission, physiology and ecology, J. Atmos. Chem., 33, 23-88, 1999.

Koehler, A.-K., Sottocornola, M., and Kiely, G.: How strong is the current carbon sequestration of an Atlantic blanket bog?, Glob. Change Biol., 17, 309-319, doi:10.1111/j.13652486.2010.02180.x, 2011.

Laine, A., Byrne, K. A., Kiely, G., and Tuittila, E.-S.: Patterns in vegetation and $\mathrm{CO}_{2}$ dynamics along a water level gradient in a lowland blanket bog, Ecosystems, 10, 890-905, 2007.

Levy, P. E., Burden, A., Cooper, M. D. A., Dinsmore, K. J., Drewer, J., Evans, C., Fowler, D., Gaiawyn, J., Gray, A., Jones, S. K., Jones, T., McNamara, N. P., Mills, R., Ostle, N., Sheppard, L. J., Skiba, U., Sowerby, A., Ward, S. E., and Zielinskli, P.: Methane emissions from soils: synthesis and analysis of a large UK data set, Glob. Change Biol., 18, 1657-1669, doi:10.1111/j.13652486.2011.02616.x, 2012.

Lohila, A., Laurila, T., Aro, L., Aurela, M., Tuovinen, J.-P., Laine, J., Kolari, P., and Minkkinen, K.: Carbon dioxide exchange above a 30-year-old Scots pine plantation established on organic-soil cropland, Boreal Environ. Res., 12, 141-157, 2007.
Lovett, G. M., Cole, J. J., and Pace, M. L.: Is net ecosystem production equal to ecosystem carbon storage?, Ecosystems, 9, 152155, 2006.

Mäkiranta, P., Riutta, T., Penttilä, T., and Minkkinen, K.: Dynamics of net ecosystem $\mathrm{CO}_{2}$ exchange and heterotrophic soil respiration following clearfelling in a drained peatland forest, Agricult. Forest Meteorol., 150, 1585-1596, 2010.

Minkkinen, K. and Laine, J.: Long-term effect of forest drainage on the peat carbon stores of pine mires in Finland, Can. J. Forest Res., 28, 1267-1275, 1998.

Ojanen, P., Minkkinen, K., Lohila, A., Badorek, T., and Penttilä, T.: Chamber measured soil respiration: a useful tool for estimating the carbon balance of peatland forest soils?, For. Ecol. Manage. 277, 132-140, 2012.

Samaritani, E., Siegenthaler, A., Yli-Petays, M., Buttler, A., Christin, P., and Mitchell, E. A. D.: Seasonal Net Ecosystem Carbon Exchange of a Regenerating Cutaway Bog: How Long Does it Take to Restore the C-Sequestration Function?, Restorat. Ecol., 19, 480-489, 2011.

Subke, J.-A., Inglima, I., and Cotrufo, M. F.: Trends and methodological impacts in soil $\mathrm{CO}_{2}$ efflux partitioning: A metaanalytical review, Global Change Biology, 12, 921-943, 2006.

Woodwell, G. M. and Whittaker, R. H.: Primary production in terrestrial ecosystems, Am. Zoologist, 8, 19-30, 1968.

Yamulki, S., Anderson, R., Peace, A., and Morison, J. I. L.: Soil $\mathrm{CO}_{2} \mathrm{CH}_{4}$ and $\mathrm{N}_{2} \mathrm{O}$ fluxes from an afforested lowland raised peatbog in Scotland: implications for drainage and restoration, Biogeosciences, 10, 1051-1065, doi:10.5194/bg-10-1051-2013, 2013.

Yamulki, S.: Interactive comment on "Comment on "Soil $\mathrm{CO}_{2}, \mathrm{CH}_{4}$ and $\mathrm{N}_{2} \mathrm{O}$ fluxes from an afforested lowland raised peatbog in Scotland: implications for drainage and restoration" by Yamulki et al. (2013)" by R. R. E. Artz et al., Biogeosciences Discuss., 10, C4228-C4228, 2013.

Yli-Petays, M., Laine, J., Vasander, H., and Tuittila, E. S: Carbon gas exchange of a re-vegetated cut-away peatland five decades after abandonment, Bor. Environ. Res., 12, 177-190, 2007.

Yu, Z. C.: Northern peatland carbon stocks and dynamics: a review, Biogeosciences, 9, 4071-4085, doi:10.5194/bg-9-40712012, 2012. 